As paediatricians become more comfortable with managing child sexual abuse, anaesthesia and sedation will be rarely necessary.

C J HOBBS

Department of Community Paediatrics, St fames's University Hospital,
1 American Academy of Pediatrics (Committee on Child Abuse and Neglect). Guidelines for the evaluation of sexual abuse of children. Pediatrics 1991; 87: 254-9.

2 Royal College of Physicians. Physical signs of sexual abuse in children. London: Royal College of Physicians, 1991.

3 Hobbs C, Wynne J. The evaluation of child sexual abuse. In.: Hobbs C, Wynne J, eds. Bailliere's clinical paediatrics, international practice and research. Child abuse. London: Bailliere Tindall, 1993: 1-29.

4 Hobbs C, Hanks H, Wynne J. Child abuse and neglect - a clinician's handbook. Edinburgh: Churchill Livingstone, 1993.

\title{
A matter of some gravity
}

The undoubted fact that children are subject to the earth's gravitational attraction is the basis of three papers in the July 1993 issue of Pediatrics.

In 1989 and 1990 in Washington State there were 2658 admissions to hospital of people aged 19 years or less with injuries caused by falling (Frederick P Rivara and colleagues, Pediatrics 1993; 92: 61-3). The numbers of admissions were fairly evenly distributed over the first four quinquennia of life and boys outnumbered girls by 1.8 to 1 . There were 11 deaths but only one was of a child younger than 10 years. Younger children most commonly fell from a height whereas adolescents commonly fell on the same level. Seventy four percent of patients had limb fractures or dislocations, $22 \%$ head injuries, $25 \%$ soft tissue injuries, and $4.5 \%$ internal injuries. The authors calculate that the annual cost of fall injuries in Washington State is about 4.5 million dollars. Each year about one child in 100 attends a casualty department after a fall and one in 10 of those is admitted to hospital.

The problem of falls from windows and balconies is addressed in a paper from Los Angeles (Deborah Lehman and Nancy Schofield, pages 121-4). Over a period of 4.5 years 158 children were admitted to the Children's Hospital, Los Angeles, having fallen from a building. The records of 151 of these children were reviewed. Ninety three fell from a window, 36 from a balcony, and 22 from other parts of the building. Ninety five percent were less than 10 years old and $54 \%$ were younger than 3 years. There was one death and 15 children were left neurologically impaired. One hundred and one children suffered fractures, most commonly of the skull. The authors suggest fresh attempts at parent education and a review of building safety regulations.

Falling off a bed is often given as an explanation when nonaccidental injury is suspected. At the Children's Hospital in Camperdown, Australia, 235 children, aged 6 years or less, fell from a cot or a bed between January 1983 and August 1992 (Thomas J Lyons and R Kim Oates pages 125-7). Thirty three were infants of less than 12 months. Twenty nine children suffered trivial injuries, mostly to the head. In addition, one child had a fractured clavicle and another a skull fracture. Neither of these injuries was in any way complicated. The maximum height fallen (climbing over cot rails) was 4.5 feet. Most children falling off a bed at home would fall a shorter distance and onto a softer surface. These authors conclude that when serious injuries are said to have resulted from falling from a bed the reliability of the history should be questioned. I think we already knew that but this study adds to the evidence. 